\title{
Perceived livelihood impacts and adaptation of vegetable farmers to climate variability and change in selected sites from Ghana, Uganda and Nigeria
}

\author{
Olushola Fadairo $^{1}$ (D) Portia Adade Williams ${ }^{2}$ (D) Faridah Sendagire Nalwanga $^{3}$
}

Received: 15 April 2019 / Accepted: 5 November 2019 / Published online: 13 November 2019

(C) The Author(s) 2019

\begin{abstract}
In the wake of deepened situations of changing climate, a clear understanding of the perceived impacts and adaptation of climate variability and change on livelihoods of vegetable farmers in Western and Eastern Africa, which is not readily available, is critical for sustainable vegetable production in Africa. Development planning for climate change vulnerability and adaptation assessment was utilised in the study. Using multi-stage sampling procedure, 193 vegetable farmers in selected sites prominent for vegetable production from Uganda, Ghana and Nigeria were used. Data were analysed using descriptive statistics, analysis of variance and linear regression at $\alpha_{0.05}$. Awareness of climate variability and change was high among most respondents from the three countries, but highest among respondents from Uganda (78.3\%). Awareness was highest for long dry spell $(\bar{x}=1.90)$ and drought $(\bar{x}=1.81)$ and lowest for harmful gas emissions $(\bar{x}=0.76)$. Changes in climate variability and trends were perceived to be highest in terms of flood volume/damage caused by flood to farmlands in Nigeria $(\bar{x}=3.85)$ and Uganda $(\bar{x}=5.0)$, but in terms of increased temperature for Ghana $(\bar{x}=4.93)$. Impact of climate-related changes on vegetable farming was high in Ghana (98.3\%) and Nigeria (46.6\%) but low in Uganda (5.0\%). Awareness $(\beta=0.14)$, perception $(\beta=0.15)$ use of adaptation strategies $(\beta=0.10)$ and household size $(\beta=-0.19)$ predicted change in perceived impact of climate variability among vegetable farmers. Vegetable farmers in Nigeria, Ghana and Uganda are affected differently by climate variability. Farmers in these countries also have different priorities for adaptation strategies. Locality-specific climate adaptation strategies would help ease farmers burden due to climate change.
\end{abstract}

Keywords Climate variability · Vegetable farming · Adaptation · Livelihood impacts . Nigeria $\cdot$ Ghana $\cdot$ Uganda

Portia Adade Williams

adadeposh@yahoo.com

Extended author information available on the last page of the article 


\section{Introduction}

Vegetables are an essential source of human nutrition and now globally recognised for nutritional security giving its richness in micronutrient contents and improved awareness on healthy eating among people in recent times. Its cultivation provides opportunity of improved income to farmers as global vegetable production has increased exponentially in the last 250 years and the world trade values of vegetables now surpass that of cereals (Bhardwaj 2012). Also, horticultural crops including vegetables are associated with more income and higher labour per hectarage of land cultivated than staple crops in smallholder farms (Williams et al. 2017a). This suggests increasing roles in generating employment opportunities for the rural population and directly linked to improving income. To ensure nutrient supply in adequate measure, an intake of $200 \mathrm{~g}$ vegetables per person each day, or $73 \mathrm{~kg}$ a year, is recommended by the Food and Agricultural Organization (FAO) (ARC 2013). This together with the improved awareness indicates the need for improved and sustainable production. Meanwhile, vegetable production is known to be sensitive to extreme weather condition, such as low soil moisture and high temperatures which are responsible for its low yields (Williams et al. 2018a; Bhardwaj 2012).

Climate variability and change have emerged as a major problem of agriculture transformation in sub-Saharan Africa with increasing experiences of unpredictable and erratic rainfall and severe temperatures threatening rural livelihoods and food security (Williams et al. 2017b; Ching et al. 2011). According to William et al. (2018a) and Datta (2013), erratic rainfall patterns and extremely high temperatures are two main climate change parameters with far-reaching impacts of agriculture in general and horticulture in particular. Mattos et al. (2014) observed that, even slight increase in average daylight temperatures and/or night can affect vegetables in terms of yield and quality. Other studies have also established that high temperature results in affecting vegetable fruit flavour, firmness, physical and physiological disorders during growth (Spaldon et al. 2015; Deuter 2014). Severe water-stress conditions are also suggested to affect vegetable productivity. In drought conditions, water reduces vegetables productivity by affecting its yield and quality and the excessive moisture during flooding also limits production during the rainy season (Bhardwaj 2012). The influence of increased temperature and rainfall uncertainties on different growth phases of vegetable development from vegetative growth to fruiting can alter the normal development and growth of plants (Spaldon et al. 2015). Ultimately, this affects crop productivity and the economic return of farmers. Moreover, climatic change influences the severity of such environmental factors in maintaining and enhancing vegetable productivity.

Climate in sub-Saharan Africa where agriculture is an important economic sector is highly variable across geographical zones. This is because agricultural production systems in this region are largely rain-fed and therefore susceptible to the vagaries of changing weather conditions. Nelson et al. (2010) expressed high degree of certainty that climate change in African countries will have adverse effects on agriculture, food security and economic advancement, especially as smallholder farmers are experiencing increased climatic variability and change. Vegetable production environment in the tropics is a blend of varied conditions of season and region (Deuter 2014). Studies in Ghana, Uganda and Nigeria have indicated expectations of extreme events and changes in precipitation and temperature (NCEA 2015a, b; Fitzmaurice 2014). In Ghana, the mainstay of the economy is agriculture, providing employment to over $50 \%$ of its workforce but is predominantly rain-fed predisposing the sector to climate change effects (NCEA 2015a). In Nigeria, agriculture 
employs about $70 \%$ of the country's population and production systems are also largely weather-sensitive making them vulnerable to climate as well (Apata 2011). Similarly, in Eastern African countries agriculture is driven by smallholders who account for more than $80 \%$ of agricultural production (Mubiru 2010). In Uganda, agriculture is the backbone of the economy and depends on rainfall, hence also a sector prone to the risks of climate variation and change (Adhikari et al. 2015).

The main causes of agricultural responses to climate change are identified as biophysical effects cum socio-economic factors (Bhardwaj 2012; Deuter 2014). These factors are likely to affect crop productivity, quality and yield and may ultimately reduce the stability of supply and threaten livelihoods of rural farmers. Meanwhile, vegetable production and productivity do not solely rest on climate impacts, but also on the agricultural systems dynamics, including ability to adjust to the changes affecting farmers and the broader industry (Spaldon et al. 2015). However, not many studies have been carried out on the impact of climate change on vegetables. In the wake of deepened situations of climate variability and change, understanding the emerging socio-economic and livelihood consequences of climate on local farmers whose livelihoods are mainly dependent on vegetable cropping is a critical step towards building appropriate adaptation and resilience strategies. To this end, a clear comparison of understanding of the climate variability and change impacts on livelihoods of vegetable farmers in Western and Eastern Africa, which is not readily available, is therefore critical for sustainable vegetable production in Africa. The main objective of this study is to investigate the local awareness and perception of climate variability and change in the last 15 years to ascertain the consequences and impacts on farmers' livelihoods and household economy and document current adaptation measures employed.

\subsection{Review of literature}

\subsubsection{Vegetable production and the climate}

Vegetables are one of the agricultural commodities and the sources of livelihood for a majority of both rural and urban populations. Vegetables are all year available, easy to cook and fast growing in nature. However, the severity of climate change threatens to deepen smallholder farmer vulnerability and undermine their prospects for development (Williams et al. 2018b).

Vegetable production faces numerous challenges besides environmental stresses such as prolonged dry spells (Williams et al. 2018a). There are several problems related to vegetable growing which include contamination associated with pathogens of leafy vegetables which is closely linked to climate change. Temperature and rainfall were found to be positively associated with the cases of salmonellosis in subtropical and tropical regions (Datta 2013; Deuter 2014). That is, climate change influences the spread of salmonellosis which is noted to increase when there is an increase in the average yearly temperature resulting from decreased latitude. Also, harsh weather conditions in the forms of heavy rains and drought have been attributed to increase in the levels of absorbed Salmonella Typhi into lettuce leaves, especially in Nigeria, where the application of contaminated irrigation water during drought spells leads to internalisation of bacteria into leafy vegetables.

Effects of changes in climate on production of vegetables include changes in the distribution of existing pests, diseases and weeds (Deuter 2014). Nelson et al. (2010) also noted that crops such as egg plants are negatively imparted by climate variation as a result of exposure to heat which reduces yields and variation in rainfall which affects production 
in areas where irrigated farming is prominent. It is noted that increase in carbon dioxide decreases the nutritive value of vegetables, while stress due to high temperature also decreases its vitamin and sugar contents. Similarly, Datta (2013) revealed that decreased precipitation and increased temperatures lead to serious crop water-stress situation due to a reduction in available water for irrigation and increase in evapo-transpiration. At the same time, rise in temperature changes production timing or planting calendar and may cause decrease in potential yields due to uncertainties of the planting season, and decrease in water available for irrigation.

Another important dimension of climate change impact on vegetable farming was reported by Oxfam (2008) in a study on poverty and climate in Uganda, where farmers attributed the disappearance of some local varieties of vegetables to climate change effect. The study reveals that farmers no longer grow a particular local variety of fluted pumpkin due to shortened period of rains, and hence early maturing types of leafy vegetables have been adopted as a replacement.

\subsubsection{Adaptation measures employed at the local level}

Climate adaptation is described as an appropriate adjustment to climate variability and change, especially for peasant farmers to enhance resilience or reduce vulnerability to its effects. Adaptation measures may be classified as anticipatory, autonomous and planned adaptation. At the local level, autonomous strategies are mostly employed and would be considered for this study. Autonomous adaptation involves a deliberate reaction to climatic stimuli prompted by ecological fluctuations in natural schemes (Below et al. 2010). Datta 2013 noted that possible avenues for vegetable industry's adaptation to climate change effects include changes in cultivars, changes in growing regions and changes in management interventions. Adaptation strategies employed across Africa include application of traditional medicine to control pests and diseases, use of water-harvesting technologies, practice of agro-forestry and conservation tillage, use of keyhole and trench gardens (Sekaleli and Sebusi 2013). Many local farmers practise mulching techniques integrating trees (fruit bearing trees and fodder trees) and other perennial as components of constructed home gardens with a mixture of crops, especially vegetables and herbs (Ishaya and Abaje 2008). This practice provides diversification of crop species and is of economic purpose because of its food and nutritional and medicinal values to the households. It also helps to reduce the problems of flooding and pollution.

Mubiru's (2010) study of Uganda states that in the dry areas, adaptation options include irrigation, migration, settling along wet corridors and cultivating along the river banks, agro-forestry and seeking alternative livelihoods. Timely planting, use of improved cultivars, variation in planting dates, multiple cropping are some adaptation practices adopted at farm level (Ndamani and Watanabe 2015). In Ghana, several adaptation strategies such as intensification of irrigation, shift from on-farm to off-farm jobs, changes in cultivation practices, seasonal migration, on-farm fertiliser application and insurance against drought effects have been recorded (Williams et al. 2018c, 2019; Bawakyillenuo et al. 2016). Others include shifts in planting period, planting drought tolerant crop varieties, planting on elevated ridges, irrigation of crops with water from streams and tree planting. Similarly, Nnadi and Ifeanyi-Obi (2014) identified planting of different varieties of crop, early harvesting of crops, use of varied dates of planting for crops, use of pest- and disease-resistant crop varieties, diversification into non-farming income activities, more frequent use 
of family labour to reduce production cost, more frequent weeding and use of indigenous knowledge as main adjustment measures used by farmers in the southern part of Nigeria.

\subsubsection{Barriers faced by local farmers}

Barriers are circumstances, situations or obstacles that lessen the efficacy of adaptation approaches (Moser and Ekstrom 2010). There exist a number of limitations to climate change adaptation among smallholder farmers but often related to limitations of technology and finance which hinders the size of adaptation in most developing countries (AntwiAgyei et al. 2013). Antwi-Agyei et al.'s (2013) study confirms implementation and lack of financial resources as barriers to adaptation. Rhodes et al.'s (2014) study in the western region of Africa identified paucity of evidence-based research on climate change and agriculture which results in inadequate knowledge and understanding of adaptation strategies and policy as barriers to effective adaptation. In a related study, poor understanding of climate change and adaptation measures, inadequate funds and better-quality seeds, and absence of water for irrigated farming among the farmers contributed to hindrances in adaptation actions (Ishaya and Abaje 2008).

In Nigeria, major factors constraining farmers' capability to adjust to changing climate have been identified to include land constraints, land tenure system, inadequate climate information and poor agricultural extension services (Oluwatusin 2014). Nhemachena and Hassan (2007) also revealed that access to information, credit, free extension services and markets are important determinants of adaption in Ghana. Additionally, Ndamani and Watanabe (2015) highlighted costly farm inputs, untimely access to meteorological information, inadequate credit facilities, lack of agricultural subsidies, poor access to agricultural extension officers and agricultural markets, limited farm size and inadequate labour as additional barriers that disenable climate adaptation in Ghana. In the Semi-Arid Areas of Eastern Africa, Mayaya et al. (2015) cited lack of resources, weak institutional support, lack of needed technical support, high cost of adaptation technologies, and uncertain climatic conditions as barriers to adaptation. Problems relating to knowledge, land-use policy, labour and water availability, and information use are also identified as key hindrance to climate change adjustment (Antwi-Agyei et al. 2013). In the recent, poor transparency in the management and utilisation of climate finance meant to promote adaptation measures including weak capacities of local institutions have been argued by authors as largely contributory to poor response to unstable climate impacts among people in remote parts of Africa (Fadairo 2018; Fadairo et al. 2017).

\section{Methodology}

\subsection{The study area}

This study was carried out in three African countries, namely Uganda, Ghana and Nigeria and used a survey method to address the study objective. These countries are part of the eight partner countries in Climate Impact Research and Capacity Leadership Enhancement (CIRCLE) Programme - an initiative of the United Kingdom Department for International Development. The following describes more specifically the sites selected from each of the three countries and as shown in Fig. 1. 


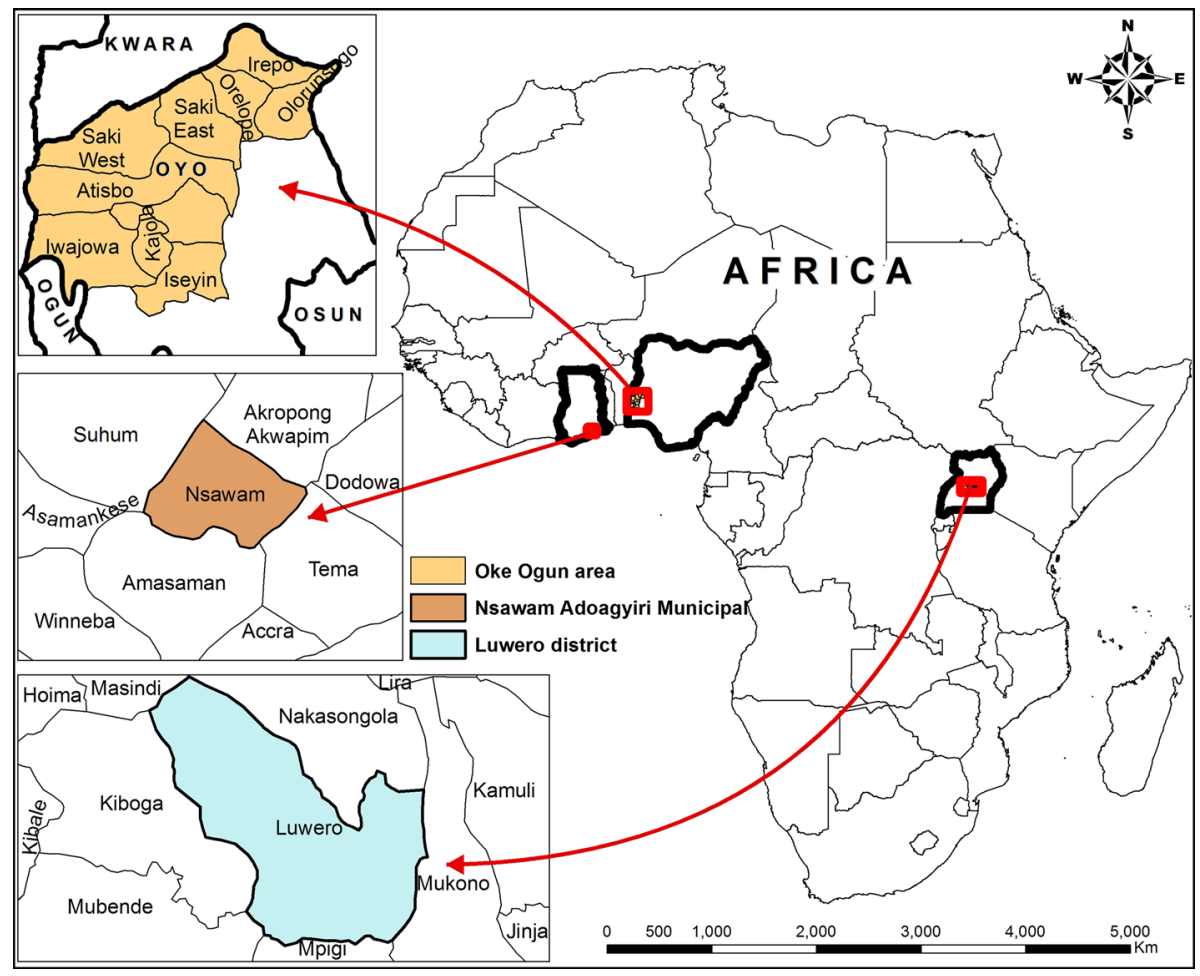

Fig. 1 Map showing the study sites

Oke-Ogun area of Oyo State (Nigeria) Oke-Ogun area is one of the four administrative zones in Oyo State, South West Nigeria and the second largest in terms of land mass. This area is situated in the northern axis of Oyo State, Nigeria, on longitude $3020^{\prime} \mathrm{E}$ and latitude $8040^{\prime} \mathrm{N}$, with mean elevation of $400 \mathrm{~m}$ above sea level. The zone comprises of ten out of the 33 Local Governments Areas (LGAs) that make up Oyo State. The zone has always been classified as the food basket of the state on account of its arable land and predominance of farming as a main source of livelihoods for many households. In addition to vegetables, the region is also known for crops such as maize, yam, cassava, and yam flour which are cultivated in commercial quantity. Oke-Ogun is prone to flood caused by climate change. The area has relatively high humidity and is characterised by two main seasons, namely dry and wet (Okeleye et al. 2016). The wet season occurs between April and October, while the dry season lasts from November to March. The annual mean temperature and precipitation are $26.3^{\circ} \mathrm{C}$ and $1227 \mathrm{~mm}$, respectively (Climate-Data n.d).

Nsawam Adoagyiri municipality (Ghana) Nsawam Adoagyiri Municipality is situated between latitude $5.45^{\prime} \mathrm{N}$ and $5.58^{\prime} \mathrm{N}$ and longitude $0.07^{\prime} \mathrm{W}$ and $0.27^{\prime} \mathrm{W}$ along the SouthEastern part of the Eastern Region of Ghana. It covers about 175 square kilometres out of the total land area of the Eastern Region. It is found in the wet climate with the main ecological zones been semi-deciduous forest and coastal savanna grassland. It experiences maxima rainfall twice with mean annual rainfall range between 1250 and $2000 \mathrm{~mm}$. Temperatures average between 26 and $30{ }^{\circ} \mathrm{C}$. Crop farming is the predominant $(94 \%)$ 
agricultural activity employing about $80 \%$ of farmers in the municipality who practise very little subsistence farming with about $60-70 \%$ as small-scale holders. The major crops grown include horticultural crops (Okro, pepper, garden eggs onion, cabbage and tomatoes pineapple, pawpaw) and other food crops (maize, cassava, plantain, and yam).

Luwero district (Uganda) Luwero is located in the central region of Uganda on $0^{\circ} 50^{\prime}$ $57 \mathrm{~N}$ (latitude) and $32^{\circ} 28^{\prime} 23 \mathrm{E}$ (longitude). It has a warm, muggy and overcast climate. There are mainly two seasons in the district, namely wet and dry. Wet season runs from March till November, while the dry period occurs between December and February. Temperature in Luwero varies from 59 to $88^{\circ} \mathrm{F}$ and is rarely below $57^{\circ} \mathrm{F}$ or above $95{ }^{\circ} \mathrm{F}$. With about 13 sub-counties, the district is one of the largest in Uganda and is predominant for peasant farming. One of the largest sub-counties in Luweero district known as Kikyusa Sub-County with 5 parishes and 31 villages was considered in this study. The five parishes include Kibengo, Kireku, Wankanya, Wabusana and Kiziba. The main economic activity carried out in this area is agriculture, and the crops grown include vegetables, fruits and cereals among others. This area experiences a tropical type of climate which favours agricultural activities over the years.

\subsection{Research design and data collection process}

The study utilised a case study approach which focused on vegetable farming in selected sites. Quantitative data were gathered using interview schedule to elicit information on respondent's perception and awareness of climate variability and trends relating to climate change in the last 15 years and the effects of climate-related changes and measures of adaptation utilised by local farmers. The interview schedule format utilised provided an opportunity to engage the farmers in further discussions on their responses, and this was helpful in discussing the results in this work.

All vegetable farmers with experience of farming of 15 years and above in the selected sites comprised the population for the study. The countries survey sites where farmers were selected were chosen based on their possibility to facilitate a better understanding of climate change impact on vegetable farmers' livelihoods and the accessibility of logistical backing, finance and time. Generally, selection of site followed a procedure of ensuring diversity of sites and representativeness of the region in terms of types of vegetable and climate. Consequent upon these considerations, six district sites were chosen across the three countries: Saki and Iseyin in Oke-ogun region of Oyo State (Nigeria); Kikyusa subcounty in Luwero district (Uganda); Panpanso, Sakyikrom and Bowkrom (Ghana). Within each of these district sites, multi-stage sampling procedure was used to sample respondents at village-level sites. The first stage involved purposive sampling of vegetable farmers with minimum of 15 years farming experience, while the second stage utilised a simple random sampling technique to sample up to $30 \%$ of the population. A total of 193 vegetable farmers comprising of 60, 73 and 60 respondents from Ghana, Nigeria and Uganda, respectively, were interviewed in the study.

\subsection{Analysis of data}

Variables for the study were measured using Likert-type scales with items generated from existing literature and past studies on rural livelihoods and climate change. Specifically, perception of respondents about climate variability and related trends was measured by 
providing a list of climate change parameters such as rainfall (quantity and duration), flood (volume and damage caused to farmlands), windstorm (violence and frequency) and temperature which farmers responded to on a five-point scale of large increase, moderate increase, constant, moderate decrease and large decrease using 15 years as reference. Perceived climate variability impact and trend on livelihoods of respondents were assessed using 13 statements encapsulated under three broad domains of income, assets and activities. The statements were measured on a five-point Liket-type scale of strongly agree to strongly disagree. Farmers' responses were scored with more positive responses awarded higher scores and in reverse order for negative responses. The Statistical Package for Social Sciences (SPSS) was used to analyse the data collected, and results were presented in tables and charts. Linear regression inferential statistic was used to determine the contributions of the independent variables to the dependent.

\section{Results}

\subsection{Respondents' socio-demographic characteristics}

Table 1 shows the respondents' personal characteristics. Most of the respondents $(74.1 \%)$ were aged 41 years and above with mean age of 47.9 years. Selection of the respondents for the study was purposely those with 15 years and above farming experience in the selected sites. This reflects why a considerably high proportion of the respondents were aged 40 years and above with more than 20 years farming experience. However, it is important for such matured farmers to impact their farming knowledge and experiences unto younger farmers to ensure continuity and sustainability in vegetable farming. Out of the 193 total respondents, majority $(71.0 \%)$ were male and had some basic-level education. Educational level of the respondents indicates that they mostly have some basic-level education. However, with few women engaged in vegetable farming, it was reported that high capital demand usually limits most women (considered resource constrained) from undertaking such farming systems in all three study areas. Women were reportedly engaged in marketing and post-harvest activities such as agro-processing. Mean years of vegetable farming, size of land cultivated and household size of the respondents were 21.2 years, 3.1 acres and 6.7 persons, respectively. Most (91.7\%) of the farmers interviewed were smallholders (farm sizes $\leq 5$ acres). Family sizes of the farmers were generally high with more than $60 \%$ of the respondents having families between 6 and 10 members. It is argued that large family size enables farmers to have enough labour for implementing various farming activities (Silvestri et al. 2012). Thus, respondents could rely on their large family sizes as support for farm labour when needed.

\subsection{Perceptions of climate variability and change}

\subsubsection{Perceived experiences and evidence of climate variability and change}

In the three study sites, all the respondents had at one time or the other heard about changing climate and most of them reported not just hearing about it but know little or more about climate change. They had mostly experienced longer dry season, drying up of streams or rivers, warmer temperature and lower rainfall pattern (Fig. 2). Famers have also 
Table 1 Distribution of respondents according to personal characteristics. Source: Data generated by the authors from a field survey $(n=193)$

\begin{tabular}{|c|c|c|c|}
\hline Variables & Frequency & Per cent & Mean $\pm \mathrm{SD}$ \\
\hline \multicolumn{4}{|l|}{ Age (years) } \\
\hline$\leq 30$ & 18 & 9.3 & \multirow{6}{*}{$47.9 \pm 11.9$} \\
\hline $31-40$ & 32 & 16.6 & \\
\hline $41-50$ & 70 & 36.3 & \\
\hline $51-60$ & 50 & 25.9 & \\
\hline $61-70$ & 17 & 8.8 & \\
\hline$\geq 71$ & 6 & 3.1 & \\
\hline \multicolumn{4}{|l|}{ Sex } \\
\hline Male & 137 & 71.0 & \\
\hline Female & 56 & 29.0 & \\
\hline \multicolumn{4}{|l|}{ Level of education } \\
\hline No formal education & 44 & 22.8 & \\
\hline Primary education & 56 & 29.0 & \\
\hline Secondary education & 80 & 41.5 & \\
\hline College/university & 10 & 5.2 & \\
\hline Others & 3 & 1.6 & \\
\hline \multicolumn{4}{|c|}{ Years of vegetable farming } \\
\hline$\leq 20$ & 109 & 56.5 & \multirow{4}{*}{$21.2 \pm 9.7$} \\
\hline $21-30$ & 73 & 37.8 & \\
\hline $31-40$ & 10 & 5.2 & \\
\hline$\geq 41$ & 1 & 0.5 & \\
\hline \multicolumn{4}{|c|}{ Size of land cultivated (acres) } \\
\hline$\leq 5$ & 177 & 91.7 & \multirow{4}{*}{$3.1 \pm 4.4$} \\
\hline $6-10$ & 12 & 6.2 & \\
\hline $11-15$ & 2 & 1.0 & \\
\hline$\geq 16$ & 2 & 1.0 & \\
\hline \multicolumn{4}{|l|}{ Household size } \\
\hline$\leq 5$ & 71 & 36.8 & \multirow{3}{*}{$6.7 \pm 2.7$} \\
\hline $6-10$ & 108 & 56.0 & \\
\hline$\geq 11$ & 14 & 7.3 & \\
\hline
\end{tabular}

experienced strong winds, severe flooding, delayed onset of rainfall and harmful gas emissions as climate change parameters but on a relatively lower awareness rate.

\subsubsection{Awareness of climate variability and change}

Irrespective of evidence of climate variability and change reported across the three study countries, a generally high awareness of the identified climate variability and changes were reported (Fig. 3). Respondents in Uganda specified the highest (78.3\%) level of awareness, followed by Ghana and Nigeria. This confirms Uganda as indeed one of the regions in Africa experiencing a relatively high level of drought impacts attributed to a combined effects of serious poverty, susceptibility to climate, natural resource depletion, social and cultural relegation, among other socio-economic development challenges and resulting in negative outcomes such as hunger, poor nutrition and low productivity of both crops and animals (Oxfam 2008). 


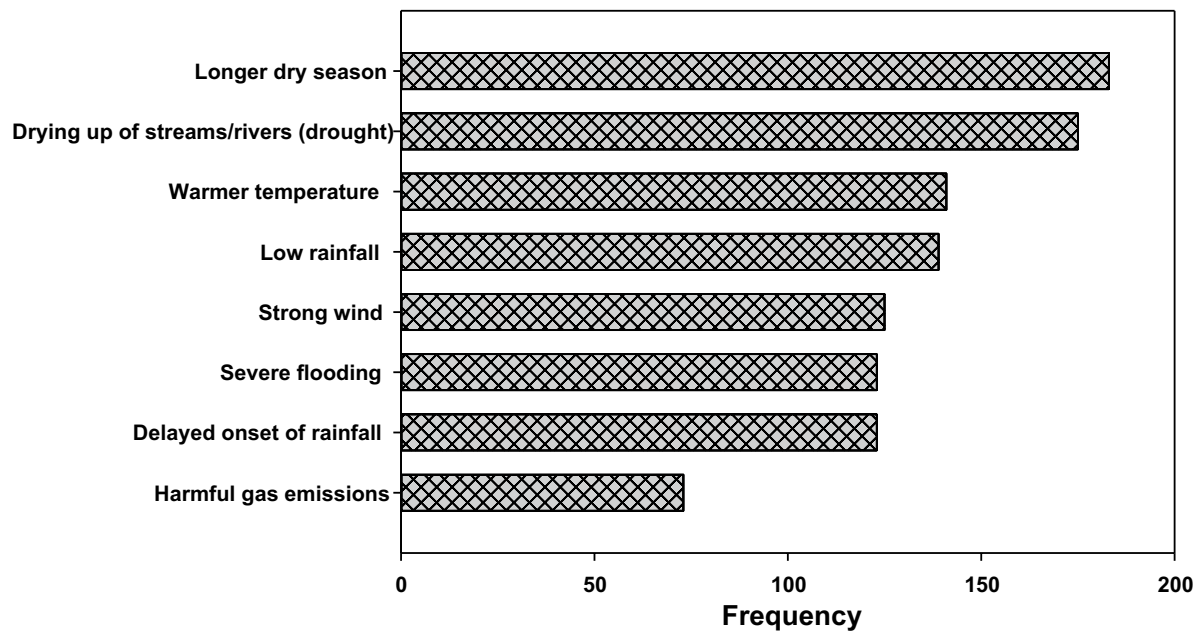

Fig. 2 Perceived experiences and evidence of climate variability and change

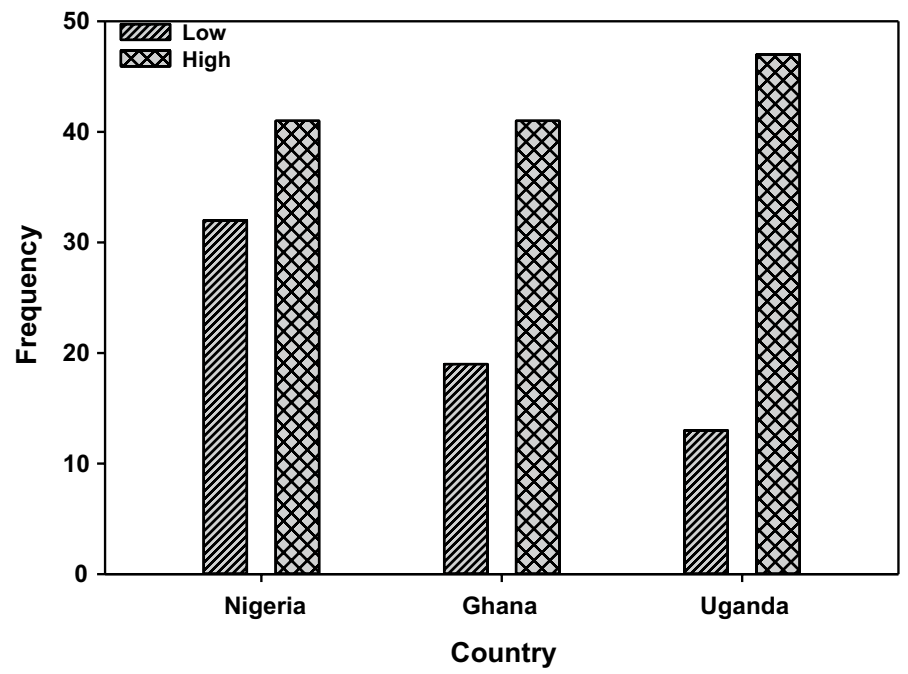

Fig. 3 Categorisation of awareness of climate variability and climate change-related trends. Source: Data generated by the authors from a field survey $(n=193)$

\subsubsection{Perceived impacts of climate variability and change on livelihoods}

Changes in climate have impacts on farmers and their livelihood activities. According to the vegetable farmers interviewed in the study areas, impacts from changing climate include declining crop yield, increase in pests and disease attack, low-quality products, crop failure, high post-harvest losses among others. Most of the vegetable farmers from Ghana and Nigeria perceived such negative climate impacts as high (Fig. 4). 


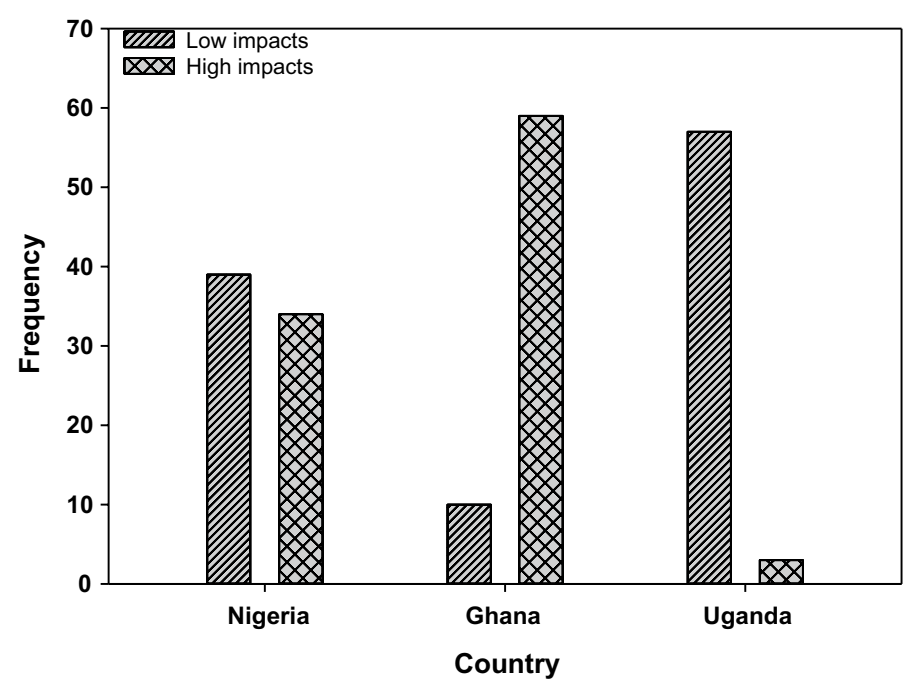

Fig. 4 Perceived impacts of climate variability and changes on respondents' livelihoods

Further, Table 2 shows the differences among the respondents from the three study locations in terms of their perception of impact of climate variation and change on their faming livelihoods. The table shows a significant difference among respondents from Ghana, Nigeria and Uganda $(F=140.75 ; p<0.05)$ with respect to impact of climate variability on their livelihoods.

\subsection{Smallholder farmers' adaptation strategies to climate variability and change}

Adjusting to climate is crucial in minimising the negative impacts from changing climate. Most of the strategies identified were at the micro-level and are processes taken to adjust farming activities and respond to changing climate. From the 17 strategies identified and presented to farmers, Table 3 shows that use of fertiliser $(\bar{x}=3.11)$, soil conservation practices such as mixed and rotational cropping $(\bar{x}=3.03)$ and making ridges across farm $(\bar{x}=2.97)$ were ranked as the top three adaptation strategies utilised among farmers in Nigeria, whereas fertiliser use $(\bar{x}=3.97)$, integrated pest management $(\bar{x}=3.30)$ and adjustment of planting calendar ranked as the highest three in Ghana. Farmers in Uganda indicated construction of channels to drain off excess water $(\bar{x}=3.85)$, building of traditional dam $(\bar{x}=3.83)$ and adjustment of planting calendar $(\bar{x}=3.78)$ as the three most used

Table 2 Analysis of variance showing differences in perceived climate impact on the respondents' livelihoods and household economy. Source: Data Generated by the Authors from a Field Survey

\begin{tabular}{llrccc}
\hline & Sum of square & $d f$ & Mean square & F & $p$ value \\
\hline Between groups & 5487.84 & 2 & 2743.92 & 140.74 & $0.00^{*}$ \\
Within groups & 3704.20 & 190 & 19.50 & & \\
Total & 9192.04 & 192 & & & \\
\hline
\end{tabular}

$S$ significant, $d f$ degree of freedom

${ }^{*} p<0.05$ 


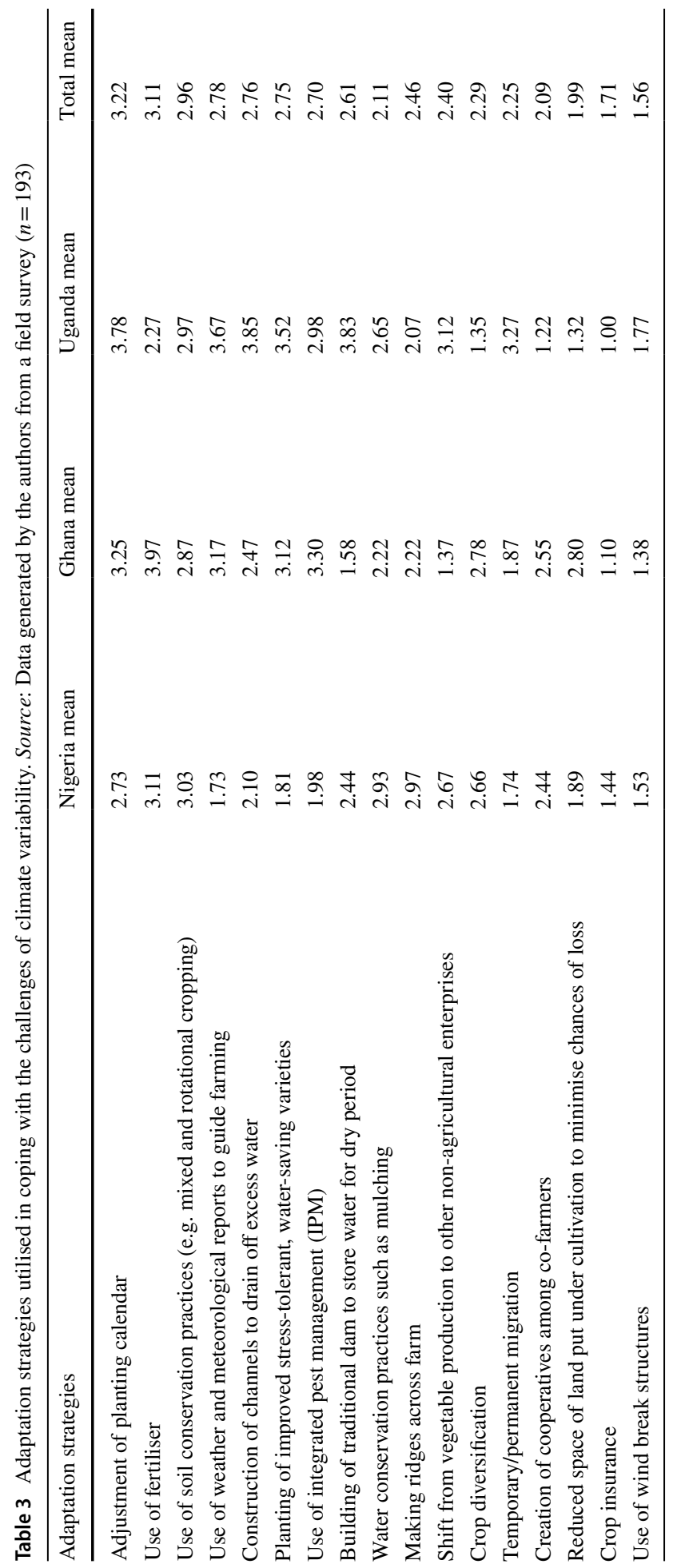


adaptation strategies. The study sites in West Africa commonly used soil fertilisation as the main measure to improve the fertility of low-fertile soils resulting from continuous cropping and erratic climatic conditions in the region. The use of channels to drain off excess water from the farming site studied in Uganda, on the other hand, was to minimise soil erosion from brief, but serious rains prevalent in the region (Oxfam 2008). Other farm practices such as crop insurance and use of wind break structures were among the least ranked strategies utilised.

\subsection{Factors influencing farmers' perception of impacts on livelihood}

It is important to understand factors affecting farmers' generally high-perceived impact of climate on their livelihood in order to guide effectively and efficiently their climate adaptation actions. Table 4 shows the contributions of independent variables (such as awareness and perception of climate variability, use of adaptation strategies, personal characteristics, sex, educational level among others) to the dependent variable (perceived impact of changing climate on livelihoods). The results show that respondents' awareness of changing climate $(\beta=0.14$; sig $<0.05)$, their perception of climate variability $(\beta=0.15$; sig $<0.05)$ and use of adaptation strategies $(\beta=0.16$; sig $<0.05)$ significantly and positively influenced their perception of climate variability impact on their livelihoods. Only $44 \%$ of the variation in the farmers' perception of impact of climate variability on their livelihoods is accounted for by the explanatory variables tested in this study.

However, respondents' household size and sources of planting materials such as research institutes and extension workers significantly but negatively influenced respondents' perception of climate variability impact on their livelihoods. Thus, farmers with larger household size and those who obtained their planting materials from research institutes and or

Table 4 Factors influencing farmers' perception of climate impacts on livelihoods. Source: Data generated by the authors from a field survey $(n=193)$

\begin{tabular}{|c|c|c|c|}
\hline & $\begin{array}{l}\text { Standardised coefficients } \\
(\beta)\end{array}$ & $t$ value & $p$ value \\
\hline Constant & & 8.74 & 0.00 \\
\hline Sex & 0.06 & 1.02 & 0.31 \\
\hline Level of education & -0.03 & -0.43 & 0.67 \\
\hline Awareness of climate change & 0.14 & 2.38 & $0.02 *$ \\
\hline Perception of climate variability & 0.15 & 2.08 & $0.04 *$ \\
\hline Adaptation strategies & 0.16 & -0.11 & $0.02 *$ \\
\hline Age of respondents & -0.01 & -1.63 & 0.91 \\
\hline Years of vegetable farming & -0.10 & 0.173 & 0.11 \\
\hline Size of land & 0.01 & -1.79 & 0.86 \\
\hline Source of planting (previous harvest) & -0.13 & -3.19 & 0.08 \\
\hline Source of planting (research institutes) & -0.30 & -4.08 & $0.00^{*}$ \\
\hline Source of planting (extension workers) & -0.40 & -3.05 & $0.00^{*}$ \\
\hline Household size & -0.19 & -1.93 & $0.00^{*}$ \\
\hline
\end{tabular}

$R=0.69, R^{2}=0.48$, adjusted $R^{2}=0.44, \mathrm{SE}=5.21, \alpha_{0.05}$

$S$ significant, $N S$ not significant

$* p<0.05$ 
extension workers perceived the impacts of climate variability on their livelihoods as lower than others who did not.

\section{Discussion}

\subsection{Impact of climate variation and change on vegetable farmers}

It is assumed that having an understanding about the fluctuations in climate gives a better guide to adaptation responses (Lemma 2016). In Eastern Africa, climate variability has been reported as erratic weather forms that will result in more risky weather parameters such as droughts, heat waves, floods and forceful storms in the decades to come (Oxfam 2008). Sylla et al. (2016) have also projected incessant and tougher warming of between 1.5 and $6.5^{\circ} \mathrm{C}$ and a broader range of uncertainty in precipitation over West Africa. These imply vegetable farmers have to adapt to ensure sustainability of their livelihoods. During discussions, it was reported that climate impacts challenges farmers productivity at the end of the production season subsequently imposing socio-economic hardship on farmers and threatening their livelihoods. This largely supports Okeleye et al.'s (2016) study that climate change generates difficulties and lead to severe losses and adversities on Nigerian farming communities due to the sensitivity of their livelihoods to adverse weather condition. In Ghana, such changes negatively affect crop productivity and lead to greater variability in yields. Farmers reported low economic returns, which even affect their socio-economic status in their communities. The data from Uganda, however, suggest that impacts were perceived as low among most of the respondents. This is plausibly due to the relatively higher level of awareness of climate variability and change among vegetable farmers in Uganda (Fig. 2). Ndamani and Watanabe (2015), Tiwari et al. (2014) and Nhemachena and Hassan (2007) observed that improved access to information and awareness enhances adaptation to climate change among farmers in studies conducted in Ghana, Nepal and Southern Africa.

Across the three sites, use of fertiliser, adjustment of planting calendar and use of soil conservation practices such as mixed and rotational cropping were among the common adaptation measures employed. Various studies on climate adaptation across Africa have widely reported on these three strategies as extensively utilised for reducing negative impact from climate change and variation (Below et al. 2010; Gbetibouo and Ringler 2009). Even though most adaptation interventions in most local spaces are not solely for the purpose of the changing climate, according to Lemma (2016), most adaptation choices have values of broad range which can be utilised as coping measures for climate change, economic state, market policy, resource accessibility and technology. For instance, agronomic practices such as mixed and rotational cropping used by smallholder farmers in reducing pest and disease attacks as well help to lessen susceptibility to the effects of variability and change. This is in consonance with Amare and Simane (2017) study in Eastern Africa where agronomic practices used by small-scale farmers in adjusting to the effects of climate variability results also in changes in plant pest and disease burdens.

Importantly, almost all the models of future climate that scientists have developed are in broad agreement that Uganda is almost certain to become wetter. The possibility of more rain is thought to be an advantage to most vegetables; hence farmers can gain more income due to more production cycles each year. West Africa is also considered a hot spot of climate change in Africa with the expectation that unprecedented climates (natural variability 
in climate) will occur (Mora et al. 2013). As farmers from the three different locations are impacted differently by climate variability and change, this directs to the need for location specific strategies in responding to the climate impacts as shown in the results (Table 3). This finding concurs with arguments by other scholars that there are no generic solutions and that for diverse smallholder farmers and varied farming systems and conditions, different adaptation strategies should be used (Douxchamps et al. 2016).

\subsection{Determinants of the impacts of climate variability and change on farmers' livelihood}

Farmers with more awareness of climate change have seen more evidence of the changes and are employing some measures to reduce the adverse impact are in a better stead to observe impacts from climate variability and change on their livelihoods. Improved awareness of climate variability thus determines to an extent the nature of farmers' disposition to the phenomenon and the extent of utilisation of adaptation measures. The more farmers utilise adaptation measures, the more they perceive climate variability to be impacting their livelihoods. More use of adaptation measures might influence farmers' perception of the impact of climate variability due to the associated additional costs, time and other valuable inputs they expend in employing these measures. The foregoing indicates the need to further enhance awareness creation on changing climate to improve adaptation planning and actions and avoid any negative climatic impacts on farmers' livelihoods. Similarly, other authors have maintained that farmers' understanding of changes in the climate is important before identifying and employing useful adaptation strategies to climate variability (Ehiakpor et al. 2016; Jiri et al. 2015; Oluwatusin 2014).

Household size and source of planting material had a significant, but negative effect on farmer's perceived climate variability impact on livelihoods. The implication is that larger family size and those who make use of institutions such as research institutes and/or extension workers as sources for their planting materials perceived lower climate variability impacts on their livelihoods than others who did not. The reason for this finding may not be far-fetched since households with more members are likely to have more hands providing labour at reduced or free cost for family farm. In the same vein, chances of obtaining improved seeds/seedlings that are climate-tolerant are higher when such agri-inputs are obtained at research institutes or from the extension workers. This finding concurs with a study by Ehiakpor et al. (2016) in Ghana which showed that household size positively influenced adaptation and impacts from climate variability and change in general. The study further argued for availability of research institutes and extension services to provide opportunities for farmers to access technical assistance, improved crop varieties and adaptation practices and technologies for an overall reduced climate impact on livelihoods. To this effect, it would be necessary to improve accessibility of research institutes and extension services to farmers.

Since it is argued that the adoption of adaptation strategies requires more human capital including labour (Ehiakpor et al. 2016), household members should be encouraged to improve their role of providing labour to assist on family farms. Moreover, horticultural crop production is labour-intensive (Williams et al. 2017b); hence, farmer's household members should be encouraged to provide labour support on farms. Additionally, the educational attainment of most of the farmers (with some level of basic education) show that improved levels of productivity could be attained as a result of increased likelihood of adopting improved production methods in all study sites. This supports Williams et al.'s 
(2018c) study on factors determining adaptation strategies to climate change among farmers confirming education as positively enhancing agricultural management and adaptation to climate change.

\section{Conclusion and recommendation}

In this study, we identified local awareness and perception of climate variability impacts on local vegetable farmers' in Ghana, Uganda and Nigeria. Despite the considerably high awareness level of changing climate among the farmers, they were affected differently by climate variability and change. As a result, farmers in Ghana and Nigeria perceived the highest climate impact on their livelihood activities. Consequently, different priorities for adaptation strategies were identified in each area. While use of fertiliser, adjustment of planting calendar and use of soil conservation practices such as mixed and rotational cropping were prevalently top-ranked strategies across the three sites, making ridges across farms, integrated pest management and building of traditional dam were different strategies identified among the most important strategies specifically in Nigeria, Ghana and Uganda, respectively.

Farmers' awareness of changing climate, perception of climate variability and use of adaptation emerged as factors influencing significantly and positively vegetable farmers' perception of climate impact on livelihoods. Consistent with other studies, we highlight the need to further enhance awareness creation on changing climate. Furthermore, to improve adaptation planning and actions, locality-specific adaptation approaches should be encouraged to reduce harsh impacts of climate on farmers' means of living.

Acknowledgements This work was supported under the Climate Impact Research Capacity and Leadership Enhancement (CIRCLE) Visiting Fellowship programme funded by the UK Department for International Development. Neither the findings nor the views expressed, however, necessarily reflect the policies of the UK Government.

Open Access This article is distributed under the terms of the Creative Commons Attribution 4.0 International License (http://creativecommons.org/licenses/by/4.0/), which permits unrestricted use, distribution, and reproduction in any medium, provided you give appropriate credit to the original author(s) and the source, provide a link to the Creative Commons license, and indicate if changes were made.

\section{References}

Adhikari, U., Nejadhashemi, A. P., \& Woznicki, S. A. (2015). Climate change and eastern Africa: A review of impact on major crops. Food and Energy Security, 4(2), 110-132.

Agricultural Research Council (ARC). (2013). Production guidelines for summer vegetables. Pretoria: Vegetables and Ornamental Plants Institute. ISBN 978-1-86949-635-7.

Amare, A., \& Simane, B. (2017). Determinants of smallholder farmers' decision to adopt adaptation options to climate change and variability in the Muger Sub basin of the Upper Blue Nile basin of Ethiopia. Agriculture \& Food Security, 6, 1-20. https://doi.org/10.1186/s40066-017-0144-2.

Antwi-Agyei, P., Dougill, A. J., \& Stringer, L. C. (2013). Barriers to climate change adaptation in sub-Saharan Africa: Evidence from northeast Ghana \& systematic literature review. Centre for Climate Change Economics and Policy; Working Paper No. 154.

Apata, T. G. (2011). Effects of global climate change on Nigerian agriculture: An empirical analysis. $C B N$ Journal of Applied Statistics, 2(1), 31-50. 
Bawakyillenuo, S., Yaro, J. A., \& Teye, J. (2016). Exploring the autonomous adaptation strategies to climate change and climate variability in selected villages in the rural northern savannah zone of Ghana. Local Environment, 21(3), 361-382.

Below, T., Artner, A., Siebert, R., \& Siebert, S. (2010). Microlevel practices to adapt to climate change for African small-scale farmers. IFPRI discussion paper 00953.

Bhardwaj, M. L. (2012). Challenges and opportunities of vegetable cultivation under changing climate scenario. A training manual on vegetable production under changing climate scenario, pp.13-18.

Ching, L., Edwards, S., \& El-Hage, S. N. (2011). Climate change and food systems resilience in subsaharan Africa. Food and Agriculture Organization of the United Nations (FAO).

Climate-Data. (n.d). Oke-Ogun weather by months. https://en.climate-data.org/africa/nigeria/kwara/okeogun-379481/. Retrieved February 2, 2019.

Datta, S. (2013). Impact of climate change in Indian horticulture-A review. International Journal of Environmental Science and Technology, 2(4), 661-671.

Deuter, P. (2014). Defining the impacts of climate change on horticulture in Australia. Reports Commissioned by the Garnaut Climate Change Review.

Douxchamps, S., Van Wijk, M. T., Silvestri, S., Moussa, A. S., Quiros, C., Ndour, N. Y. B., et al. (2016). Linking agricultural adaptation strategies, food security and vulnerability: Evidence from West Africa. Regional Environmental Change, 16, 1305-1317. https://doi.org/10.1007/s1011 3-015-0838-6.

Ehiakpor, D. S., Danso-Abbeam, G., \& Baah, J. E. (2016). Cocoa farmer's perception on climate variability and its effects on adaptation strategies in the Suaman district of western region, Ghana. Cogent Food \& Agriculture, 2(1), 1210557. https://doi.org/10.1080/23311932.2016.1210557.

Fadairo, O. S. (2018). Corruption and the imbalance in climate finance flows in Sub Sahara Africa: The case of cross river, Nigeria and lessons for social science researchers. In S. Kudo \& F. Kapfudzaruwa (Eds.), Tackling sustainable development in Asia and Africa (Vol. 1, pp. 48-70). Denver: Spears Media Press LLC. ISBN 978-1-942876-30-4.

Fadairo, O. S., Calland, R., Mulugetta, Y., \& Olawoye, J. E. (2017). A corruption risk assessment of reducing emissions from deforestation and forest degradation project in Nigeria. International Journal of Climate Change: Impact and Responses, 10(1), 1-22.

Fitzmaurice, M. M. (2014). Hot times ahead: The effects of climate change on agriculture in India and Nigeria. Global Majority E-Journal, 89.

Gbetibouo, G. A., \& Ringler, C. (2009). Mapping South African farming sector vulnerability to climate change and variability: A subnational assessment (pp. 2-4). International Food Policy Research Institute (IFPRI) and Center for Environmental Economics and Policy in Africa (CEEPA).

Ishaya, S., \& Abaje, I. B. (2008). Indigenous people's perception on climate change and adaptation strategies in Jema'a local government area of Kaduna State, Nigeria. Journal of Geography and Regional Planning, 1(8), 138.

Jiri, O., Mafongoya, P., \& Chivenge, P. (2015). Smallholder farmer perceptions on climate change and variability: A predisposition for their subsequent adaptation strategies. Journal of Earth Science and Climate Change, 6, 277. https://doi.org/10.4172/2157-7617.1000277.

Lemma, W. A. (2016). Analysis of smallholder farmers' perceptions of climate change and adaptation strategies to climate change: The case of western Amhara Region, Ethiopia Doctoral thesis University of South Africa.

Mattos, L. M., Moretti, C. L., Jan, S., Sargent, S. A., Lima, C. E. P., \& Fontenelle, M. R. (2014). Climate changes and potential impacts on quality of fruit and vegetable crops, Chap. 19. In Emerging technologies and management of crop stress tolerance (pp. 467-486). Cambridge: Academic Press. https://doi.org/10.1016/B978-0-12-800876-8.00019-9.

Mayaya, H. K., Opata, G., \& Kipkorir, E. C. (2015). Understanding climate change and manifestation of its driven impacts in the semi arid areas of Dodoma Region, Tanzania. Ethiopian Journal of Environmental Studies and Management, 8(4), 364-376.

Mora, C., Frazier, A. G., Longman, R. J., Dacks, R. S., Walton, M. M., Tong, E. J., et al. (2013). The projected timing of climate departure from recent variability. Nature, 502, 183-187. https://doi. org/10.1038/nature 12540 .

Moser, S. C., \& Ekstrom, J. A. (2010). A framework to diagnose barriers to climate change adaptation. Proceedings of the National Academy of Sciences, 107(51), 22026-22031.

Mubiru, D. N. (2010). Climate change and adaptation options in Karamoja. Organ: Food Agric.

Ndamani, F., \& Watanabe, T. (2015). Farmers' perceptions about adaptation practices to climate change and barriers to adaptation: A micro-level study in Ghana. Water, 7(9), 4593-4604.

Nelson, V., Morton, J. F., Chancellor, T., Burt, P., \& Pound, B. (2010). Climate change, agriculture and Fairtrade: Identifying the challenges and opportunities. NRI working paper series. 
Netherlands Commission for Environmental Assessment (NCEA). (2015a). Climate change profile: Ghana. Netherlands Ministry of Foreign Affairs, Wageningen Centre for Development Innovation Netherlands Water Partnership and Dutch Sustainability Unit.

Netherlands Commission for Environmental Assessment (NCEA). (2015b). Climate change profile: Uganda. Netherlands Ministry of Foreign Affairs, Wageningen Centre for Development Innovation Netherlands Water Partnership and Dutch Sustainability Unit.

Nhemachena, C., \& Hassan, R. (2007). Micro-level analysis of farmers' adaptation to climate change in Southern Africa. International Food Policy Research Institute, Washington, DC, USA. IFPRI discussion paper, 00714.

Nnadi, F. N., \& Ifeanyi-Obi, C. C. (2014). Climate change adaptation measures used by farmers in southsouth Nigeria. Journal of Environmental Science, Toxicology and Food Technology, 8(4), 1-6.

Okeleye, S. O., Olorunfemi, F. B., Sogbedji, J. M., \& Aziadekey, M. (2016). Impact assessment of flood disaster on livelihoods of farmers in selected farming communities in Oke-Ogun region of Oyo state, Nigeria. International Journal of Scientific and Engineering Research, 7(8), 2067-2083.

Oluwatusin, F. M. (2014). The perception of and adaptation to climate change among cocoa farm households in Ondo State, Nigeria. Academic Journal of Interdisciplinary Studies, 3, 147-156.

Oxfam. (2008). Turning up the heat: Climate change and poverty in Uganda. http://www.satnet.org.ug/ downloads/OXFAM\%20Climate\%20change\%20and\%20poverty\%20in\%20Uganda.pdf. Retrieved February 2, 2019. ISBN: 978-1-84814-039-4.

Rhodes, E. R., Jalloh, A., \& Diouf, A. (2014). Review of research and policies for climate change adaptation in the agriculture sector in West Africa. Future Agricultures. Working paper, 90.

Sekaleli, T. S. T., \& Sebusi, K. (2013). Farmers' response and adaptation strategies to climate change in Mafeteng district, Lesotho. African Technology Policy Studies Network, ATPS Working Paper No. 74.

Silvestri, S., Bryan, E., Ringler, C., Herrero, M., \& Okoba, B. (2012). Climate change perception and adaptation of agro-pastoral communities in Kenya. Regional Environmental Change, 12(4), 791-802.

Spaldon, S., Samnotra, R. K., \& Chopra, S. (2015). Climate resilient technologies to meet the challenges in vegetable production. International Research on Current and Academic Review, 3(2), $28-47$.

Sylla, M. B., Nikiema, P. M., Gibba, P., Kebe, I., \& Klutse, N. A. B. (2016). Climate change over West Africa: Recent trend future projections. In J. A. Yaro \& J. Hesselberg (Eds.), Adaptation to climate change and variability in rural West Africa. Cham: Springer. https://doi.org/10.1007/978-3-319-31499 -0 .

Tiwari, K. T., Rayamajhi, S., Pokharel, R. K., \& Balla, M. K. (2014). Determinants of the climate change adaptation in rural farming in Nepal Himalaya. International Journal of Multidisciplinary and Current Research, 2, 2321-3124.

Williams, P. A., Crespo, O., \& Abu, M. (2018a). Assessing vulnerability of horticultural smallholders' to climate variability in Ghana: Applying the livelihood vulnerability approach. Environment, Development and Sustainability. https://doi.org/10.1007/s10668-018-0292-y.

Williams, P. A., Crespo, O., \& Abu, M. (2019). Adapting to changing climate through improving adaptive capacity at the local level-The case of smallholder horticultural producers in Ghana. Climate Risk Management. https://doi.org/10.1016/j.crm.2018.12.004.

Williams, P. A., Crespo, O., Abu, M., \& Simpson, N. P. (2018b). A systematic review of how vulnerability of smallholder agricultural systems to changing climate is assessed in Africa. Environmental Research Letters, 13, 5-6. https://doi.org/10.1088/1748-9326/aae026.

Williams, P. A., Crespo, O., Atkinson, C. J., \& Essegbey, G. O. (2017a). Impact of climate variability on pineapple production in Ghana. Agriculture \& Food Security, 6, 1-2. https://doi.org/10.1186/s4006 6-017-0104-x.

Williams, P. A., Crespo, O., \& Essegbey, G. O. (2017b). Economic implications of a changing climate on smallholder pineapple production in Ghana. Journal of Economics and Sustainable Development, 8, 34-43.

Williams, P. A., Tete-Larbi, R., Yeboah, I., \& Frempong, G. K. (2018c). Smallholder farmers experiences of climate variability and change on pineapple production in Ghana: Examining adaptation strategies for improved production. Journal of Agricultural Extension and Rural Development, 10, 35-43. https:// doi.org/10.5897/JAERD2017.0919.

Publisher's Note Springer Nature remains neutral with regard to jurisdictional claims in published maps and institutional affiliations. 


\section{Affiliations}

\section{Olushola Fadairo $^{1}$ (D) Portia Adade Williams ${ }^{2}$ (D) $\cdot$ Faridah Sendagire Nalwanga $^{3}$}

Olushola Fadairo

dairom2@gmail.com

Faridah Sendagire Nalwanga

faridahnalwanga2012@gmail.com

1 Department of Agricultural Extension and Rural Development, University of Ibadan, Ibadan, Nigeria

2 CSIR - Science and Technology Policy Research Institute, P. O. Box CT 519, Cantonments, Accra, Ghana

3 Department of Geography, Geo Informatics and Climatic Sciences, Makerere University, Kampala, Uganda 